\title{
Monika Sadowska
}

Wyższa Szkoła Inżynierii i Zdrowia, Warszawa

monika.b.sadowska@gmail.com

ORCID: https://orcid.org/0000-0002-0450-1975

\section{Zaniedbania \\ podczas badania podmiotowego \\ jako przesłanka odpowiedzialności \\ za błąd diagnostyczny}

http://dx.doi.org/10.12775/SIT.2018.039

Rozpoznanie stanu zdrowia pacjenta stanowi pierwszy i najważniejszy krok w procesie terapeutycznym. Jednakże postawienie nieprawidłowej diagnozy może pociągać za sobą wybór niewłaściwych metod i środków leczenia, a w konsekwencji prowadzić do utraty szans wyleczenia lub poprawy stanu zdrowia pacjenta. Dlatego uważa się, że błąd diagnostyczny, inaczej zwany błędem rozpoznania, jest tym, który wywiera najbardziej dotkliwe konsekwencje ${ }^{1}$. Ten rodzaj błędu polega bądź na mylnym stwierdzeniu nieistniejącej choroby (błąd pozytywny), bądź częściej na nierozpoznaniu rzeczywistej choroby pacjenta (błąd negatywny) ${ }^{2}$. Niektórzy autorzy wyróżniają jeszcze tzw. błąd diagnostyczny mieszany, polegający na tym, że lekarz wprawdzie rozpoznaje chorobę, ale jest to choroba inna

${ }^{1}$ M. Nesterowicz, Prawo medyczne, Toruń 2013, s. 231.

${ }^{2}$ P. Zieliński, Kilka słów o pojęciu oraz rodzajach błędu medycznego, „Medyczna Wokanda” 2016, nr 8, s. 189. 
niż ta, na którą faktycznie cierpi pacjent ${ }^{3}$. Każdy $z$ wymienionych rodzajów błędu diagnostycznego w konsekwencji może prowadzić do pogorszenia stanu zdrowia chorego $z$ reguły poprzez wadliwe prognozowanie i leczenie lub zaniechanie czynności terapeutycznych $^{4}$. Stąd wydaje się, że poza uprzednio wymienionymi można dodatkowo wyróżnić błąd diagnostyczny aktywny, polegający na zastosowaniu wadliwej metody lub techniki diagnostycznej czy też na niewłaściwym postępowaniu pracownika medycznego w procesie diagnozowania pacjenta, lub błąd diagnostyczny pasywny wyrażający się zaniechaniem zastosowania wymaganej w danej sytuacji zdrowotnej pacjenta czynności medycznej ${ }^{5}$.

Ryzyko popełnienia błędu medycznego diagnostycznego często jest utożsamiane wyłącznie $z$ wykonywaniem zawodu lekarza. Stąd należałoby wyjaśnić, że ze względu na posiadane kompetencje przedstawicieli innych zawodów medycznych, np. pielęgniarek, położnych, ratowników medycznych, fizjoterapeutów, diagnostów laboratoryjnych ${ }^{6}$, również ich działania obarczone są ryzykiem popełnienia błędu w zakresie oceny stanu zdrowia pacjenta, a w konsekwencji podjęcia błędnej decyzji terapeutycznej, a zgromadzone przez nich informacje medyczne mogą stanowić podstawę błędnej decyzji lekarza.

${ }^{3}$ A. Fiutak, Klasyfikacja błędów medycznych, „Medycyna Rodzinna” 2010, nr 2, s. 51.

${ }^{4}$ M. Nesterowicz, Prawo, s. 233.

${ }^{5}$ A. Górski, Leksykon prawa medycznego. 100 podstawowych pojęć, Warszawa 2012, s. 5.

${ }^{6}$ Zob. art. 4 i 5 oraz 15b Ustawy z dnia 15 lipca 2011 r. o zawodach pielęgniarki i położnej, tekst jedn.: Dz.U. z 2018 r. poz. 123 ze zm. (dalej: u.z.p.p.); art. 3 i 7 Rozporządzenia Ministra Zdrowia z dnia 28 lutego 2017 r. w sprawie rodzaju i zakresu świadczeń zapobiegawczych, diagnostycznych, leczniczych i rehabilitacyjnych udzielanych przez pielęgniarkę albo położną samodzielnie bez zlecenia lekarskiego, Dz.U. z 2017 r. poz. 497; Ustawa z dnia 27 lipca 2001 r. o diagnostyce laboratoryjnej, tekst jedn.: Dz.U. z 2016 r. poz. 2245 ze zm. (dalej: u.d.1.); art. 4 Ustawy z dnia 25 września 2015 r. o zawodzie fizjoterapeuty, Dz.U. z 2015 r. poz. 505 ze zm. (dalej: u.z.f.); art. 11 Ustawy z dnia 8 września 2006 r. o Państwowym Ratownictwie Medycznym, tekst jedn.: Dz.U. z 2017 r., poz. 2195 ze zm. (dalej: u.r.m.), szerzej o wykonywaniu zawodu diagnosty laboratoryjnego A. Augustynowicz, 
Praktyka sądowa dowodzi, że błąd diagnostyczny jest przez pracownika medycznego przeważnie zawiniony na skutek niedołożenia należytej staranności w ustaleniu przesłanek, na których oparł swoją diagnozę ${ }^{7}$ Innymi słowy, gdyby osoba wykonująca zawód medyczny działała $z$ wymaganą przezornością, mogłaby tego błędu uniknąć ${ }^{8}$. Pojęcie należytej staranności może być rozumiane obiektywnie jako przestrzeganie ściśle określonych reguł i najczęściej sformalizowanych oraz precyzyjnie określonych zasad postępowania, pozwalających na bezpieczne, a zarazem skuteczne wykonywanie danej interwencji medycznej ${ }^{9}$. Natomiast w znaczeniu subiektywnym - jako osobiste zaangażowanie się, czyli osobisty emocjonalno-racjonalny stosunek do wykonywania danej czynności medycznej ${ }^{10}$, wykazanie przez daną osobę wystarczającej uwagi i dokładności w wykonywaniu zawodu ${ }^{11}$. Stąd działanie lub postępowanie $z$ uwzględnieniem należytej staranności wymaga przestrzegania określonych sformalizowanych reguł medycznych, będących pochodną nauki i obecnego stanu wiedzy specjalistycznej, wiedzy racjonalnej, czyli zdroworozsądkowej i działania z odpowiednim zaangażowaniem swej uwagi, jakiego wymaga dana sytuacja ${ }^{12}$.

Niemniej jednak postępowanie pracownika medycznego w określonej sytuacji należy oceniać $z$ uwzględnieniem całokształtu okoliczności istniejących w chwili podejmowania czynności medycznej, a zwłaszcza tych danych, którymi osoba ta dysponowała albo mogła

H. Owczarek, Dobro pacjenta $w$ wykonywaniu zawodu diagnosty laboratoryjnego, „Journal of Laboratory Diagnostics” 2012, nr 1, s. 77-86.

7 M. Nesterowicz, Prawo medyczne. Komentarze i glosy do orzeczeń sądowych, Warszawa 2014, s. 86 i 115; A. Fiutak, Prawo medyczne $w$ orzecznictwie z komentarzem, Warszawa 2012, s. 29 i 33.

8 M. Nesterowicz, Prawo medyczne. Komentarze, s. 233.

${ }^{9}$ E. Zielińska, Ustawa o zawodach lekarza i lekarza dentysty. Komentarz, Warszawa 2008, s. 79.

${ }^{10}$ M. Patryn, Określenie zasady postępowania lekarza z należyta starannością z płaszczyzny orzecznictwa sądowego, „Prawo i Medycyna” 2017, nr 2, http://www.prawoimedycyna.pl/sklep/1067/okreslenie-zasady- postepowanialekarza-z-nalezyta-starannością-z-plaszczyzny-orzecznictwa-sadowego--pim-47 (dostęp: 7.02.2017 r.).

11 E. Zielińska, Ustawa o zawodach, s. 79.

${ }^{12}$ M. Nesterowicz, Prawo, s. 87. 
dysponować, mając na uwadze wymagania aktualnej wiedzy medycznej i nauki oraz powszechnie przyjętej praktyki. Przyjmuje się pewien poziom „fachowości”, poniżej którego postępowanie lekarza, pielęgniarki, położnej, ratownika medycznego, diagnosty laboratoryjnego, fizjoterapeuty należy ocenić negatywnie ${ }^{13}$.

Brak należytej staranności w procesie oceny stanu zdrowia pacjenta i stawiania diagnozy może być spowodowany powierzchownością badania pacjenta lub wręcz zaniechaniem jego wykonania, nieprzeprowadzeniem specjalistycznych badań pomocniczych lub złą interpretacją uzyskanych wyników badań. Powierzchowność ustalana jest w relacji do ogólnego wymogu zachowania należytej staranności przez osobę wykonującą zawód medyczny. Badanie należy uznać za powierzchowne, jeśli będzie odbiegało od przeciętnego, powszechnie przyjętego w praktyce i uznanego za mieszczące się $\mathrm{w}$ ramach lege artis badania $\mathrm{w}$ analogicznych sytuacjach ${ }^{14}$. Przy czym przez lege artis należy rozumieć postępowanie zgodnie ze wskazaniami aktualnej wiedzy medycznej, czyli z obowiązującymi standardami, procedurami, zaleceniami, jak też rekomendacjami towarzystw naukowych określającymi postępowanie w określonej sytuacji klinicznej ${ }^{15}$. Należy przy tym nadmienić, że w trakcie studiów adepci zawodów medycznych nabywają wiedzę i umiejętności z zakresu badania podmiotowego i przedmiotowego pacjenta ${ }^{16}$. Ponadto osoba wykonująca zawód lekarza jest zobowiązana do doskonalenia zawodowego, w szczególności w różnych formach kształcenia podyplomowego ${ }^{17}$. Z kolei pielęgniarka i położna mają

13 Ibidem, s. 93.

${ }^{14}$ Wyrok Sądu Najwyższego z dnia 1 kwietnia 2008 r., IV KK 381/07, Lex nr 404571.

15 J. Zajdel, Moc prawna standardów medycznych i wytycznych praktyki klinicznej, http://pra- wo.mp.pl/publikacje/prawomedyczne/52342, moc-prawna-standardow-medycznych-i-wytycznych- praktyki-klinicznej (dostęp: 23.03.2017 r.).

${ }^{16}$ Rozporządzenie Ministra Nauki i Szkolnictwa Wyższego z dnia 9 maja 2012 r. w sprawie standardów kształcenia dla kierunków studiów: lekarskiego, lekarsko-dentystycznego, farmacji, pielęgniarstwa i położnictwa, Dz.U. z 2012 r. poz. 63.

17 Zob. art. 19 Ustawy z dnia 5 grudnia 1996 r. o zawodach lekarza i lekarza dentysty, tekst. jedn.: Dz.U. z 2018 r., poz. 617 ze zm. (dalej: u.z.1.). 
obowiązek stałego aktualizowania swojej wiedzy i umiejętności zawodowych oraz prawo do doskonalenia zawodowego w różnych rodzajach kształcenia podyplomowego ${ }^{18}$. Tożsamy obowiązek dotyczy ratowników medycznych (art. 12 u.r.m.), diagnostów laboratoryjnych (art. 30 u.d.1.), fizjoterapeutów ${ }^{19}$. Reasumując, na osobie wykonującej zawód medyczny ciąży obowiązek doskonalenia zawodowego w sposób umożliwiający zastosowanie w praktyce klinicznej wiedzy medycznej najbardziej aktualnej, przy czym wybór, czy zastosować najnowocześniejszą metodę diagnostyki lub leczenia, czy też tą, która jest stosowana od lat, ale ma opinię sprawdzonej, powinien zależeć od stanu zdrowia pacjenta, wskazań i przeciwwskazań do jej przeprowadzenia, umiejętności profesjonalisty medycznego, a przede wszystkim prawnie skutecznej zgody pacjenta na zastosowanie zaproponowanej interwencji medycznej. Niewątpliwie niedozwolone jest wykorzystanie metody diagnostycznej niezgodnej $\mathrm{z}$ aktualnie dostępną wiedzą medyczną, negatywnie ocenionej na gruncie nauk medycznych ${ }^{20}$.

W orzecznictwie zwrócono uwagę, że wprowadzenie nowoczesnych technik diagnostycznych nie umniejsza wartości podstawowych elementów badania fizykalnego pacjenta, jakie stanowi wywiad i badanie przedmiotowe ${ }^{21}$. Ponadto zaniechanie przeprowadzenia badania fizykalnego pacjenta lub jego niedokładne zbadanie stanowi naruszenie reguł wiedzy i praktyki medycznej. Obowiązek bezpośredniego, osobistego przeprowadzenia przez lekarza badania pacjenta wynika $z$ przepisów zawartych w ustawie o zawodach lekarza i lekarza dentysty oraz z Kodeksu etyki lekarskiej ${ }^{22}$. Podobnie

18 Zob. art. 61 Ustawy z dnia 15 lipca 2011 r. o zawodach pielęgniarki i położnej, tekst jedn.: Dz.U. z 2018 poz. 123 ze zm. (dalej: u.z.p.p.).

19 Zob. art. 6 Kodeksu etyki fizjoterapeuty Rzeczypospolitej Polskiej, http:// zgptf2.linuxpl.info/files/kodeks.pdf (dostęp: 8.10.2018 r.) w związku z art. 4 ust. 1 u.z.f.

${ }^{20}$ M. Sadowska, Bład medyczny $w$ świetle innowacji technologicznych na rynku usług zdrowotnych, w: Prawo a technologie medyczne, red. M. Sadowska, K. Kukuryk, Lublin 2017, s. 54-70.

${ }^{21}$ Wyrok Sądu Apelacyjnego w Gdańsku z dnia 23 października 2013 r., I ACa 866/11, Lex nr 1396851.

${ }^{22}$ Zob. art. 42 u.z.l. oraz art. 9 Kodeksu etyki lekarskiej (dalej: KEL), przy tym należy wyjaśnić, że wprawdzie KEL nie stanowi źródła prawa, jednakże 
pielęgniarka i położna, która posiada kwalifikacje uprawniające ją do samodzielnego ordynowania leków oraz wyrobów medycznych, obowiązana jest uprzednio przeprowadzić osobiście badanie fizykalne pacjenta (art. 15b u.z.p.p.). Oczywiście nie oznacza to, że w innych okolicznościach obowiązek badania pacjenta jest zniesiony. Trudno bowiem wyobrazić sobie wykonywanie zawodu pielęgniarki i położnej, w szczególności udzielanie świadczeń zdrowotnych wskazanych w przepisach art. 4 ust. 1 i 5 ust. 1 u.z.p.p. ${ }^{23}$,

jego przepisy mogą stanowić miernik oceny zachowania lekarza i jego postępowania oraz wskazówkę interpretacyjną przy dokonywaniu kwalifikacji prawnej działania bądź zaniechania lekarza, i tym samym wpływać na odpowiedzialność dyscyplinarną, cywilną oraz karną. Normy zawarte w KEL doprecyzowują i uzupełniają przepisy rangi ustawowej i w związku $z$ tym powinny być brane pod uwage przy wykonywaniu zawodu lekarza. Już bowiem w przyrzeczeniu lekarskim zawarte zostały odniesienia do korzystania ze współczesnej wiedzy lekarz przyrzeka bowiem wykonywać zawód wedle najlepszej wiedzy oraz stale poszerzać swoją wiedzę lekarską.

${ }^{23}$ Wykonywanie zawodu pielęgniarki polega na udzielaniu świadczeń zdrowotnych, w szczególności na: 1) rozpoznawaniu warunków i potrzeb zdrowotnych pacjenta; 2) rozpoznawaniu problemów pielęgnacyjnych pacjenta; 3) planowaniu i sprawowaniu opieki pielęgnacyjnej nad pacjentem; 4) samodzielnym udzielaniu w określonym zakresie świadczeń zapobiegawczych, diagnostycznych, leczniczych i rehabilitacyjnych oraz medycznych czynności ratunkowych; 5) realizacji zleceń lekarskich w procesie diagnostyki, leczenia i rehabilitacji; 6) orzekaniu o rodzaju i zakresie świadczeń opiekuńczo-pielęgnacyjnych; 7) edukacji zdrowotnej i promocji zdrowia. Wykonywanie zawodu położnej polega na udzielaniu świadczeń zdrowotnych, w szczególności na: 1) rozpoznawaniu ciąży, sprawowaniu opieki nad kobietą w przebiegu ciąży fizjologicznej, a także prowadzeniu w określonym zakresie badań niezbędnych w monitorowaniu ciąży fizjologicznej; 2) kierowaniu na badania konieczne do jak najwcześniejszego rozpoznania ciąży wysokiego ryzyka; 3) prowadzeniu porodu fizjologicznego oraz monitorowaniu płodu $z$ wykorzystaniem aparatury medycznej; 4) przyjmowaniu porodów naturalnych, w przypadku konieczności także $\mathrm{z}$ nacięciem krocza, a w przypadkach nagłych także porodu z położenia miednicowego; 5) podejmowaniu koniecznych działań w sytuacjach nagłych, do czasu przybycia lekarza, w tym ręcznego wydobycia łożyska, a w razie potrzeby ręcznego zbadania macicy; 6) sprawowaniu opieki nad matką i noworodkiem oraz monitorowaniu przebiegu okresu poporodowego; 7) badaniu noworodków i opiece nad nimi oraz podejmowaniu w razie potrzeby wszelkich niezbędnych działań, w tym natychmiastowej reanimacji; 8) realizacji zleceń lekarskich w procesie diagnostyki, leczenia i rehabilitacji; 9) samodzielnym udzielaniu 
bez przeprowadzenia badania pacjenta, a przede wszystkim badania podmiotowego, planowanie bowiem określonych działań medycznych jest uzależnione od wyników oceny stanu zdrowia pacjenta, jego potrzeb terapeutycznych i pielęgnacyjnych.

Błąd diagnostyczny należy postrzegać jako powstały również w takiej sytuacji, w której osoba wykonująca zawód medyczny, uprawniona do wykonania badania fizykalnego, przeprowadza badanie przedmiotowe, ale nie poprzedza go właściwym, rzetelnym i dociekliwym wywiadem. Wywiad powinien obejmować fakty dotyczące aktualnego stanu zdrowia pacjenta, w szczególności odnoszące się do odczuwanych dolegliwości, ich charakteru, czasu trwania, okoliczności ich wystąpienia, jak też przebytych i współistniejących chorób oraz czynników środowiskowych mających wpływ na stan zdrowia. Informacje te pracownik medyczny pozyskuje od samego pacjenta oraz osób bliskich, często członków rodziny.

Trudno sobie w ogóle wyobrazić sytuację, jak twierdzi Sąd Najwyższy w wyroku z dnia 1 kwietnia 2008 r., w której badanie fizykalne nie jest poprzedzone wywiadem, i to wywiadem nie „byle jakim”, lecz takim, w którym lekarz docieka przebiegu i objawów zgłaszanej choroby oraz chorób przebytych, tylko bowiem taki wywiad wręcz warunkuje poprawność stawianej diagnozy i zastosowanie następnie właściwej terapii ${ }^{24}$. Mylna diagnoza może być wynikiem nie tylko nieuzyskania informacji o pacjencie lub od pacjenta, ale też niezapoznania się $z$ informacjami zgromadzonymi podczas wywiadu, a zawartymi w dokumentacji medycznej. Tym samym zaniechanie wywiadu, jego niedbałe przeprowadzenie lub nieuwzględnienie ze-

w określonym zakresie świadczeń zapobiegawczych, diagnostycznych, leczniczych i rehabilitacyjnych; 10) profilaktyce chorób kobiecych i patologii położniczych; 11) rozpoznawaniu u matki lub dziecka objawów nieprawidłowości wymagających skierowania do lekarza; 12) sprawowaniu opieki położniczo-ginekologicznej nad kobietą; 13) prowadzeniu działalności edukacyjno-zdrowotnej w zakresie: a) przygotowania do życia w rodzinie, metod planowania rodziny oraz ochrony macierzyństwa i ojcostwa, b) przygotowywania do rodzicielstwa oraz pełnego przygotowania do urodzenia dziecka, łącznie $z$ poradnictwem na temat higieny i żywienia.

${ }^{24}$ Wyrok Sądu Najwyższego z dnia 1 kwietnia 2008 r., IV KK 381/07, Lex nr 404571. 
branych podczas rozmowy z pacjentem informacji należy oceniać jako sprzeczne $z$ wymaganą należytą starannością ${ }^{25}$.

Badanie podmiotowe powinno być oczywiście przeprowadzone z poszanowaniem prawa pacjenta do intymności ${ }^{26}$, w warunkach zapewniających swobodne prowadzenie rozmowy umożliwiające pacjentowi przekazywanie informacji dla niego krępujących. Ponadto zasadą jest formułowanie pytań w sposób dla pacjenta zrozumiały, dostosowany do jego poziomu intelektualnego, $z$ uwzględnieniem jego wieku i percepcji ${ }^{27}$. Nie można przy tym zapominać, że pacjent małoletni ma prawo do wyrażenia swojego zdania i informacji w zakresie potrzebnym do prawidłowego przebiegu procesu diagnostycznego i terapeutycznego, $z$ uwzględnieniem stopnia rozwoju psychofizycznego dziecka ${ }^{28}$. Stąd prowadzenie wywiadu wyłącznie z rodzicem dziecka, lecz bez wysłuchania małoletniego, w przypadku, kiedy stopień jego rozwoju pozwala na przeprowadzenie rozmowy, nie jest postępowaniem prawidłowym. Nie jest także właściwe zachowanie lekarza, który ignoruje spostrzeżenia rodzica co do stanu zdrowia dziecka, jak bowiem twierdził August Bier ${ }^{29}$, „spostrzegawcza mama stawia często lepszą diagnozę niż mało doświadczony lekarz".

Na negatywną ocenę zasługuje także praktyka stosowana wobec pacjentów w wieku podeszłym, mianowicie prowadzenie wywiadu wyłącznie $z$ rodziną pacjenta, który często ze względu na występujące u niego dysfunkcje percepcji słuchowej i wzrokowej, czy też zaburzenia mowy wymaga większej cierpliwości, wyrozumiałości,

${ }^{25}$ R. Kędziora, Odpowiedzialność karna lekarza w zwiąku z wykonywaniem czynności medycznych, Warszawa 2009, s. 212.

${ }^{26}$ Zob. art. 20 ust. 1 Ustawy $z$ dnia 8 listopada 2008 r. o prawach pacjenta i Rzeczniku Praw Pacjenta, tekst. jedn.: Dz.U. z 2017 r. poz. 1318 ze zm. (dalej: u.p.p.), a także art. 36 u.z.l., szerzej o prawie pacjenta do poszanowania intymności i godności D. Karkowska, Ustawa o prawach pacjenta i Rzeczniku Praw Pacjenta. Komentarz, Warszawa 2012, s. 306-323 oraz E. Zielińska, Ustawa o zawodach lekarza i lekarza dentysty. Komentarz, Warszawa 2008, s. 662-667.

27 D. Dyk, Badanie fizykalne $w$ pielegniarstwie, Warszawa 2013, s. 19-28.

${ }^{28}$ Zob. art. 9 ust. 7, a także art. 31 ust. 7 u.z.l.

${ }^{29}$ August Bier (24 listopada 1861-12 marca 1949) - niemiecki chirurg, pionier znieczulenia rdzeniowego, profesor medycyny na uniwersytetach w Greifswaldzie oraz w Bonn. 
a przede wszystkim przeznaczonego na rozmowę czasu, który można „zaoszczędzić”, uzyskując informacje od osób bliskich w zdecydowanie krótszym czasie.

Problematyczną kwestią jest także możliwość przeprowadzenia badania podmiotowego $z$ pacjentem głuchoniemym, zwłaszcza w nagłej sytuacji zdrowotnej. Wprawdzie podmiot leczniczy ${ }^{30}$ zobowiązany jest respektować prawo osoby uprawnionej do skorzystania z pomocy osoby przybranej31, jak też zapewnić możliwość korzystania przez nią $z$ pomocy wybranego tłumacza języka migowego lub tłumacza-przewodnika, to jednak w praktyce realizacja tego uprawnienia napotyka trudności natury organizacyjnej, zwłaszcza w sytuacji nagłej. Z przepisów Ustawy z dnia 19 sierpnia $2011 \mathrm{r}$. o języku migowym i innych środkach komunikowania się (tekst jedn.: Dz.U. z 2017, poz. 1824) nie wynika, w jaki sposób podmiot leczniczy ma zapewnić możliwość korzystania przez osobę niesłyszącą z pomocy tłumacza czy osoby przybranej. Brak tej precyzji powoduje, że w rzeczywistości to na głuchoniemym pacjencie spoczywa obowiązek zorganizowania sobie tłumacza w sytuacji korzystania ze świadczeń zdrowotnych.

Bariera komunikacyjna nie może utrudniać pacjentom niesłyszącym dostępu do świadczeń zdrowotnych i aktywnego uczestnictwa w procesie ich udzielania. W rzeczywistości brak jest unormowań prawnych zabezpieczających prawa pacjentów niesłyszących i niedosłyszących przed nieporozumieniami wynikającymi z niedokładności językowej stwarzającej zagrożenie, które może mieć wpływ na decyzje terapeutyczne, a w konsekwencji na zdrowie pacjenta głuchoniemego. Stąd tak ważne jest zwiększanie świadomości społecznej dotyczącej prawnej odpowiedzialności świadczeniodawców

30 Podmiot leczniczy w rozumieniu art. 4 ust. 1 Ustawy z dnia 15 kwietnia 2011 r. o działalności leczniczej, Dz.U. z 2016 poz. 2190 ze zm.

${ }^{31}$ Osoba, która ukończyła 16 lat i została wybrana przez osobę uprawnioną $\mathrm{w}$ celu ułatwienia porozumienia $\mathrm{z}$ osobą uprawnioną i udzielenia jej pomocy w załatwieniu spraw w organach administracji publicznej, jednostkach systemu, podmiotach leczniczych, jednostkach policji, straży pożarnej i straży gminnych oraz jednostkach ochotniczych działających w tych obszarach (art. 3 pkt 1 Ustawy $z$ dnia 19 sierpnia 2011 r. o języku migowym i innych środkach komunikowania się, tekst jedn.: Dz.U. z 2017 r., poz.1824). 
za zapewnienie pacjentom poczucia bezpieczeństwa w jednostkach ochrony zdrowia poprzez eliminowanie barier komunikacyjnych ${ }^{32}$. Przeszkody oraz błędy w komunikacji interpersonalnej między pracownikiem medycznym a pacjentem mogą spowodować ograniczenie w uzyskaniu informacji od pacjenta, co będzie skutkowało mylnym rozpoznaniem stanu zdrowia, a w konsekwencji zastosowaniem niewłaściwych metod diagnostycznych ${ }^{33}$. Jednocześnie należy pamiętać, że osoba udzielająca świadczenia zdrowotnego jest bezwzględnie zobowiązana do bezpośredniego, osobistego, starannego przeprowadzenia badania fizykalnego, którego podstawowym elementem jest wywiad $z$ pacjentem.

W ocenie Sądu Apelacyjnego w Warszawie prawidłowe zebranie wywiadu niejednokrotnie przesądza o powodzeniu procesu diagnostycznego, a zaniedbanie lekarza w tym przedmiocie stanowi przesłankę odpowiedzialności za błąd diagnostyczny ${ }^{34}$. W sprawie rozpoznawanej przez wskazany sąd lekarz dyżurny, badając pacjentkę zgłaszającą się z urazem głowy, nie przeprowadził w należyty sposób wywiadu, którego niezbędnym elementem jest rozmowa $z$ rodziną bądź osobami towarzyszącymi, co do okoliczności zdarzenia, w którym poszkodowana doznała urazu oraz objawów chorobowych, jakie mu towarzyszyły. Mianowicie, w ocenie sądu, wywiad przeprowadzony z pacjentem - osobą z poważnym urazem głowy, zbolałą, cierpiącą i przestraszoną - z oczywistych względów, wynikających chociażby z zasad logicznego myślenia, nie może być uznany za wystarczający i prawidłowy. Świadczy więc o niedochowaniu przez lekarza należytej staranności przy badaniu pacjentki. Zdaniem sądu za wywiad nie można uznać krótkich zdawkowych rozmów na korytarzu, „przy okazji”, w momencie wejścia i wyjścia pacjenta $z$ gabinetu lekarskiego czy też w momencie skierowania pacjenta na badanie diagnostyczne.

${ }^{32}$ Zob. E. Kale, H.R. Syed, Language barriers and the use of interpreters in the public health services. A questionnaire-based survey, „Patient Educ Couns” 2010, nr 81, s. 187-191.

${ }^{33}$ R. Kędziora, Odpowiedzialność karna, s. 212.

${ }^{34}$ Wyrok SA w Warszawie $z$ dnia 9 lutego 2010 r., VI ACa 786/09, Lex nr 672510 . 
Osoba wykonująca zawód medyczny, udzielająca świadczeń zdrowotnych, jest także obowiązana do dokumentowania wykonywanych czynności medycznych, w tym wyników przeprowadzonego badania fizykalnego pacjenta ${ }^{35}$. Ponadto $\mathrm{w}$ karcie badania podmiotowego powinna znaleźć się adnotacja o przeprowadzeniu wywiadu z członkami rodziny pacjenta lub osobami bliskimi, posiadającymi informacje, które mogą mieć znaczenie dla prowadzenia procesu terapeutycznego. Dokumentowanie tego rodzaju czynności medycznej należy jeszcze do rzadkości, a wbrew pozorom ma bardzo duże znaczenie praktyczne w kontekście wykazania należytej staranności ze strony osoby sprawującej opiekę nad pacjentem.

Lekarz ma obowiązek wykonywać zawód zgodnie ze wskazaniami aktualnej wiedzy medycznej, dostępnymi mu metodami i środkami zapobiegania, rozpoznawania i leczenia chorób, zgodnie $z$ zasadami etyki zawodowej oraz $z$ należytą starannością (art. 4 u.z.1.). Pielęgniarka i położna także obowiązana jest wykonywać zawód z należytą starannością, zgodnie $z$ zasadami etyki zawodowej, poszanowaniem praw pacjenta, dbałością o jego bezpieczeństwo, wykorzystując wskazania aktualnej wiedzy medycznej (art. 11 ust. 1 u.z.p.p.). W przypadkach wątpliwych osoba wykonująca zawód medyczny ma obowiązek kontrolować dokładność swojej diagnozy lekarskiej czy pielęgniarskiej - wszelkimi dostępnymi jej środkami ${ }^{36}$. $\mathrm{W}$ przypadkach niepewnych powinna powtórzyć badanie ${ }^{37}$. Dotyczy to także badania fizykalnego, w tym wywiadu. Jeżeli podczas jednorazowej rozmowy $\mathrm{z}$ pacjentem $\mathrm{w}$ związku $\mathrm{z}$ udzielaniem świadczenia

35 Obowiązek prowadzenia dokumentacji medycznej pacjenta przez osoby wykonujące zawód medyczny wynika z przepisów zawartych w art. 41 u.z.l. oraz art. 18 u.z.p.p., przy czym sposób prowadzenia, udostępniania i przechowywania dokumentacji medycznej określają przepisy zawarte są w rozdziale 7 u.p.p., natomiast rozwiązania szczegółowe w sprawie dokumentacji medycznej regulowane są w drodze rozporządzeń wykonawczych, m.in. Rozporządzenia Ministra Zdrowia z dnia 9 listopada 2015 r. w sprawie rodzaju, zakresu i wzorów dokumentacji medycznej oraz sposobu jej przetwarzania, Dz.U. z 2015 r. poz. 2069.

${ }^{36}$ M. Nesterowicz, Prawo, s. 233.

37 A. Sieńko, Błędy medyczne - odpowiedzialność lekarza i placówki medycznej. Jak unikać kosztownych pułapek, Warszawa 2015, s. 68. 
zdrowotnego uzyskane informacje okażą się niewystarczające, niepełne lub wątpliwe, osoba realizująca świadczenie powinna wywiad pogłębić poprzez powtórne zadanie pytań pacjentowi bądź jego rodzinie. Jeżeli istnieje taka możliwość, np. w trakcie hospitalizacji, to kolejną rozmowę powinno przeprowadzić się w kolejnych dniach pobytu pacjenta w szpitalu.

Sąd Najwyższy w wyroku z dnia 20 marca $2002 \mathrm{r}^{38}$ uznał, że błędem diagnostycznym było zakwalifikowanie do zabiegu wyłyżeczkowania przez lekarza bez specjalizacji oraz przeprowadzenie tego zabiegu bez nadzoru specjalisty ginekologa. Błędem było także dwukrotne rozpoznanie żywej ciąży, po ponownym przyjęciu powódki do szpitala, wyłącznie na podstawie badania USG i wdrożenie leczenia w celu podtrzymania faktycznie nieistniejącej ciąży. Pacjentka zgłosiła się do szpitala po poronieniu i związanym $z$ tym nieprawidłowym krwawieniem $z$ dróg rodnych. Lekarz natomiast stwierdził żywą ciążę. Na skutek błędnej diagnozy i uzyskiwania sprzecznych informacji o stanie zdrowia i podejmowanych wzajemnie wykluczających się metod leczniczych u pacjentki wystąpił rozstrój zdrowia polegający na znoszeniu cierpień psychicznych, co uzasadniało w ocenie sądu przyznanie jej zadośćuczynienia. W przedmiotowej sprawie w ocenie Sądu Najwyższego zabrakło ze strony lekarza należytej staranności oraz wymaganej wiedzy. Zawiodła także komunikacja, w tym prawidłowo przeprowadzony wywiad podczas przyjęcia pacjentki do szpitala, jak też w trakcie hospitalizacji, co pozwoliłoby na uniknięcie wadliwego postępowania.

Podobnie wypowiedział się Sąd Apelacyjny w Łodzi ${ }^{39}$, oceniając postępowanie lekarza jako zaniedbanie w postaci braku należytej staranności w zebraniu szczegółowego wywiadu przed podaniem znieczulenia, co stanowiło podstawę do planowania dalszego postępowania. Sąd w uzasadnieniu swojego wyroku wskazał, że wprawdzie w dniu zdarzenia podmiot leczniczy posiadał personel medyczny oraz odpowiednie wyposażenie, spełniał również wymogi fachowe

${ }^{38}$ Wyrok Sądu Najwyższego z dnia 20 marca 2002 r., V CKN 909/00, Lex nr 56027.

${ }^{39}$ Wyrok Sądu Apelacyjnego w Łodzi z dnia 5 grudnia 2014 r., I ACa 1224/14, Lex nr 1665107. 
i sanitarne w zakresie standardów postępowania i procedur medycznych przy zabiegach anestezjologicznych i intensywnej terapii. Niemniej jednak na podjęcie decyzji o znieczuleniu ogólnym nie może mieć decydującego wpływu tylko wyposażenie gabinetu, lecz przede wszystkim ogólny stan zdrowia pacjenta. W efekcie, zdaniem sądu, należało uznać, że gdyby badanie podmiotowe i przedmiotowe zostało przeprowadzone przez lekarza wnikliwie, to uzyskałby informacje o istnieniu przeciwwskazań do zastosowania znieczulenia ogólnego w warunkach ambulatoryjnych. Przeprowadzone przez lekarza badanie podmiotowe ograniczyło się do krótkiej rozmowy z matką dziecka tuż przed rozpoczęciem znieczulenia, było zbyt pobieżne i nie zawierało istotnych szczegółów odnośnie do przyjmowanych przez dziecko leków, alergii, wykonanych przed zabiegiem badań dotyczących wady serca. Lekarz dopuścił się także uchybień w przeprowadzeniu badania przedmiotowego przed zastosowaniem znieczulenia ogólnego. Badanie to było bowiem zbyt wąskie, sprowadziło się do osłuchania klatki piersiowej, zmierzenia tętna oraz jednorazowego pomiaru ciśnienia tętniczego. Lekarz nie zbadał jamy ustnej dziecka pod kątem rozmiarów języka, choć ma to znaczenie dla drożności dróg oddechowych. Jednocześnie okoliczność, że anestezjolog uzyskał od matki małoletniej pacjentki informację, że dziecko wcześniej było leczone stomatologicznie w znieczuleniu ogólnym bez powikłań, nie może usprawiedliwiać jego decyzji co do zastosowania znieczulenia ogólnego ani umniejszać jego winy.

W praktyce medycznej nie można wykluczyć sytuacji, kiedy to pacjent wprowadza osobę udzielającą świadczenia medycznego w błąd, podając nieprawdziwe informacje ${ }^{40}$. Może dokonywać tego w sposób świadomy, chcąc pewne informacje zataić, lub też może nie wiedzieć o znaczeniu przekazywanych informacji dla podejmowanych decyzji terapeutycznych. Czynnik ten trudno jest wyeliminować, jednakże należy mieć świadomość jego istnienia i starać się go przynajmniej na tyle kontrolować, by poprzez staranne działanie,

40 J. Witkowski, Błąd lekarski: ryzyko popetnienia a kwestia obiektywizmu $w$ orzekaniu, „Prawo i Medycyna” 2009, http://www.prawoimedycyna.pl/ index.php?str=artykul\&id=163\&PHPSESSID=281 10c71 704ca4550a (dostęp: 7.02.2018 r.). 
dostępnymi metodami i środkami oraz z poszanowaniem zasad etyki zawodowej dążyć do poznania faktycznego stanu zdrowia pacjenta, aby w wyniku tego rozpoznania wdrożone działania terapeutyczne były adekwatne do rzeczywistej choroby ${ }^{41}$.

Udzielenie pacjentowi wyjaśnień co do konieczności przekazywania przez niego prawdziwych informacji dotyczących jego stanu zdrowia i czynników nań wpływających jest niezbędne dla uzyskania wiarygodnych wyników badania podmiotowego, a w konsekwencji dla oceny faktycznego stanu klinicznego pacjenta i podjęcia adekwatnych interwencji medycznych.

Nadmienić przy tym należy, że obowiązek udzielania informacji istnieje po stronie profesjonalisty, jest wyrazem respektowania prawa pacjenta do świadomego udziału w podejmowaniu decyzji dotyczących jego zdrowia ${ }^{42}$. Należy również pamiętać o zapewnieniu pacjentowi warunków do poszanowania intymności, gdyż w przeciwnym razie zakres i treść przekazywanych przez pacjenta informacji może ulec znacznemu ograniczeniu w sposób przez niego zamierzony, ze względu na ochronę jego dóbr osobistych albo z uwagi na właściwe każdemu człowiekowi naturalne uczucie skrępowania i wstydu.

Zdaniem Sądu Najwyższego wyrażonym w wyroku z dnia 8 lutego 2017 r. ${ }^{43}$ lekarz nie może poprzestać na przyjęciu od pacjenta wywiadu co do przebytych przez niego chorób i operacji także wtedy, gdyby pacjent zapewniał, że był i jest zdrowy. W przedmiotowej sprawie do szpitala trafił pacjent $z$ raną uda. Został poddany zabiegowi operacyjnemu i skierowany na oddział chirurgiczny. Pacjent miał widoczne żylaki nóg. Mimo tego lekarz prowadzący nie wdrożył u niego leczenia przeciwzakrzepowego. Kilka dni później pacjent zmarł z powodu zatoru zakrzepowego tętnicy płucnej.

${ }^{41}$ A. Wnukiewicz-Kozłowska, Pułapki codziennej praktyki lekarskiej. Błędy diagnostyczne i terapeutyczne a odpowiedzialność lekarza, „Medium Gazeta Dolnośląskiej Izby Lekarskiej” 2015, nr 4, s. 1.

42 D. Karkowska, Ustawa o prawach pacjenta i Rzeczniku Praw Pacjenta. Komentarz, Warszawa 2012, s. 151.

${ }^{43}$ Wyrok Sądu Najwyższego z dnia 8 lutego 2017 r., III KK 226/16, Lex nr 2224610. 
Lekarz został oskarżony o nieumyślne spowodowanie śmierci pacjenta. Sąd rejonowy uniewinnił oskarżonego od zarzucanego mu przestępstwa, a sąd okręgowy utrzymał wyrok. Sądy przyjęły, że oskarżony lekarz w okolicznościach, w których wykonał zabieg, mógł nie zauważyć żylaków u leżącego chorego, gdyż ujawniają się one dopiero w pozycji pionowej. Natomiast Sąd Najwyższy stwierdził, że podstawową powinnością prawną gwaranta jest zachowanie „ostrożności wymaganej w danych okolicznościach”. W realiach sprawy za takie okoliczności, w rozumieniu tego przepisu, trzeba uznać te, w jakich oskarżony przystąpił do wykonania zabiegu chirurgicznego, polegającego na zaopatrzeniu rany szarpanej uda z uszkodzeniem mięśni i ścięgien. Do wykonania zabiegu nie wolno było przystąpić bez sprawdzenia, czy nie istnieje zagrożenie powikłania w postaci powstania zatoru zakrzepowego. Do tego obligowały lekarza chirurga standardy profilaktyki przeciwzakrzepowej. Naruszenie tej powinności oznaczałoby ewidentne niezachowanie ostrożności wymaganej w zaistniałych okolicznościach. Biegli potwierdzili zgodnie w swoich opiniach, że na lekarzu operatorze ciążył ów obowiązek, oraz wyjaśnili, jakich czynności diagnostycznych powinien był on dokonać przed przystąpieniem do zabiegu; zaliczyli do nich konieczność przeprowadzenia rzetelnego badania przedmiotowego. Sąd Najwyższy zwrócił uwagę, że chirurg jest obowiązany do podejmowania określonych czynności medycznych w celu zapobieżenia negatywnym skutkom dla zdrowia pacjenta. Musi więc działać $z$ rozeznaniem i należytą starannością. Powinien był zatem przeprowadzić dokładny wywiad oraz oględziny ciała chorego i dopiero wówczas operować.

Ustalenie błędu medycznego, w tym diagnostycznego, zależy od uzyskania odpowiedzi na pytanie, czy postępowanie lekarza w konkretnej sytuacji i z uwzględnieniem całokształtu okoliczności istniejących w chwili zabiegu, a zwłaszcza tych danych, którymi wówczas dysponował lub mógł dysponować, zgodne było z wymaganiami aktualnej wiedzy medycznej oraz powszechnie przyjętej praktyki. Źródłem informacji o stanie zdrowia pacjenta jest sam pacjent. Stąd badanie podmiotowe, czyli rozmowa $z$ pacjentem, a niejednokrotnie także $z$ osobami mu towarzyszącymi stanowi podstawę uzyskania zasadniczych informacji o faktycznym stanie 
zdrowia, o towarzyszących pacjentowi dolegliwościach, występujących niepokojących objawach, okolicznościach ich wystąpienia, czasie trwania, chorobach współistniejących i szeregu innych informacji, zwanych medycznymi, $z$ racji ich przydatności do oceny stanu zdrowia pacjenta i powzięciu odpowiedniej do wyników tej oceny decyzji terapeutycznej.

Jednocześnie w świetle powyższego niezrozumiałe są twierdzenia medyków, jak i prawników zasłyszane na salach rozpraw, że lekarz „nie posiadał wiedzy” o objawach wskazujących na rzeczywisty stan zdrowia pacjenta. To przecież od osoby udzielającej świadczenia zdrowotnego zależy, na ile będzie staranna w pozyskaniu informacji o stanie zdrowia pacjenta, na ile wykaże się cierpliwością, dociekliwością, których to cech niestety niejednokrotnie brakuje pracownikom medycznym, co można stwierdzić, biorąc pod uwagę charakterystykę błędów medycznych i ich przyczyn, w oparciu o analizę orzecznictwa sądowego.

Zadaniem sądu będzie ustalenie, czy błędne rozpoznanie było usprawiedliwione występującymi objawami, czy wynikało z przyczyn zawinionych przez osobę udzielającą świadczenia zdrowotnego, $\mathrm{np}$. nieprzeprowadzenia koniecznych badań $z$ powodu zaniechania rozmowy z pacjentem czy też $z$ osobami towarzyszącymi pacjentowi, a będącymi świadkami pogorszenia stanu zdrowia ${ }^{44}$. Stąd odpowiedzialność będzie zależała od możności postawienia osobie obowiązanej do udzielenia świadczenia zdrowotnego $z$ należytą starannością zarzutu niewłaściwego postępowania.

Błędy diagnostyki i terapii, opieszałość w podejmowaniu czynności i niedostateczne pouczenie pacjenta o ryzyku związanym ze stanem zdrowia to przesłanki odpowiedzialności osób wykonujących zawody medyczne ${ }^{45}$. Gdyby postępowanie tychże osób było prawidłowe, jeżeliby wykonywały swoje obowiązki z dołożeniem należytej staranności, przezorności i przewidywalności skutków swojego postępowania, to $\mathrm{w}$ wielu sytuacjach do wyrządzenia pacjentowi szkody by nie doszło.

\footnotetext{
${ }^{44}$ M. Nesterowicz, Prawo, s. 231.

${ }^{45}$ Ibidem, s. 238.
} 
Jak potwierdza praktyka orzecznicza, błędy diagnostyczne są często wynikiem ignorancji, lekceważenia reguł prawnych i zasad kodeksu etyki zawodowej. Nie bez znaczenia jest nieprawidłowa organizacja pracy, ujawniająca się m.in. niedoborem pracowników medycznych o konkretnych kwalifikacjach, brakiem sprzętu diagnostycznego lub brakiem osób kompetentnych do jego obsługi, brakiem podstawowych lub specjalistycznych narzędzi i materiałów niezbędnych do prawidłowego, zgodnego $z$ aktualną wiedzą medyczną procesu terapeutycznego. Niemniej jednak prawidłowo przeprowadzonego wywiadu z pacjentem i osobami jemu towarzyszącymi, $z$ jednoczesnym poszanowaniem godności i intymności pacjenta oraz przysługujących mu praw nie jest w stanie zastąpić żadna nowoczesna aparatura. Rozmowa $z$ pacjentem wymaga od pracownika medycznego przede wszystkim staranności, cierpliwości, dociekliwości i znajomości podstawowych zasad komunikacji interpersonalnej. $Z$ jednej strony to niewiele, a $z$ drugiej, czego nie sposób nie zauważyć, to, co wydaje się najmniej skomplikowane, przysparza najwięcej trudności. Oczywiście zgubne są rutyna i pośpiech, które w rzeczywistości udzielania świadczeń zdrowotnych nie powinny mieć miejsca, a jednak istnieją i powodują, że to, co najważniejsze, czyli dobro pacjenta, schodzi na dalszy plan.

Przyczyny zaniechania badania podmiotowego lub jego niedbałe przeprowadzenie bywają różne. Najczęściej jednak spowodowane są rutyną i uznaniem danego przypadku klinicznego za błahy ${ }^{46}$. Całkiem odmienną kwestią jest problematyka realizacji badania podmiotowego u osób głuchoniemych. W świetle obowiązujących przepisów brakuje precyzyjnych regulacji zapewniających bezpieczeństwo pacjentów głuchoniemych w nagłych sytuacjach zdrowotnych, wymagających udziału osoby umożliwiającej ich komunikowanie się $z$ pracownikami medycznymi, co zapewniałoby dostęp i korzystanie ze świadczeń zdrowotnych z poszanowaniem autonomii pacjenta, czyli pełnego i świadomego udziału w stosowanych interwencjach medycznych.

${ }^{46}$ R. Kędziora, Odpowiedzialność karna lekarza, s. 210. 
W powyższych okolicznościach niewątpliwie należy się zgodzić $z$ twierdzeniem prezentowanym przez Wojciecha Lisa, którego zdaniem dla powodzenia przedsięwzięć ukierunkowanych na zapewnienie bezpieczeństwa zdrowotnego pacjentów konieczna jest zmiana mentalności wśród osób wykonujących zawody medyczne i przejście od traktowania pacjenta w sposób dyrektywny do postrzegania go jako partnera w dyskusji i aktywnego uczestnika w procesie terapeutycznym, zwłaszcza że podejmowane wobec niego interwencje medyczne nie powinny niweczyć jego prawa do samostanowienia ${ }^{47}$.

\section{STRESZCZENIE}

Zaniedbania podczas badania podmiotowego

jako przesłanka odpowiedzialności za błąd diagnostyczny

Nierozpoznanie choroby pacjenta bądź mylne stwierdzenie nieistniejącego schorzenia jest niejednokrotnie wynikiem nieprawidłowo prowadzonego procesu diagnostycznego, $\mathrm{w}$ tym zaniedbania $\mathrm{w}$ realizacji jednego $\mathrm{z}$ zasadniczych elementów, jakim jest badanie podmiotowe. Zaniechanie przeprowadzenia wywiadu lub niedokładne zebranie informacji medycznych od pacjenta stanowi naruszenie reguł wiedzy i praktyki medycznej, jak też jest sprzeczne $z$ wymaganą należytą starannością.

Warunkiem przyjęcia, że doszło do błędu diagnostycznego z powodu zaniedbania $\mathrm{w}$ przeprowadzeniu badania podmiotowego, jest ustalenie, że postępowanie pracownika medycznego było obiektywnie niezgodne ze wskazaniami współczesnej wiedzy medycznej oraz miało charakter zawiniony, tj. że postępowanie to $\mathrm{w}$ danych okolicznościach sprawy może być przedmiotem zarzutu oraz że było nieprawidłowe, przy uwzględnieniu surowych wymagań stawianych osobowym wykonującym zawody medyczne w zakresie profesjonalizmu postępowania.

Słowa kluczowe: błąd medyczny; błąd diagnostyczny; badanie fizykalne; odpowiedzialność odszkodowawcza; prawa pacjenta

${ }^{47}$ W. Lis, Bezpieczeństwo zdrowotne pacjentów $w$ świetle obowiąujacych przepisów, w: Prawna ochrona zdrowia pacjentów, red. J. Pacian, Warszawa 2017, s. 27. 


\title{
SUMMARY
}

\author{
Negligence during subject examination as the premise \\ of responsibility for diagnostic error
}

\begin{abstract}
Unrecognized patient's disease or erroneous statement of a non-existing disease is often the result of incorrectly conducted diagnostic process, including negligence in the implementation of one of the essential elements, which is the subject examination. Failure to conduct an interview or inaccurate collection of medical information from a patient is a violation of the rules of medical knowledge and medical practice, as well as being contrary to the required due diligence.

A condition of admission that there was a diagnostic error occurred due to negligence in carrying out a subject examination is to establish that the behavior of the medical professional was objectively inconsistent with the indications of modern medical knowledge and was culpable, i.e. that the proceeding may be the subject of the charge under the circumstances of a particular case and that it was incorrect, taking into account the strict requirements imposed on the medical professionals in terms of their professionalism.
\end{abstract}

Keywords: medical error; diagnostic error; physical examination; liability for damages; patient's rights

\section{BIBLIOGRAFIA}

Augustynowicz A., Owczarek H., Dobro pacjenta $w$ wykonywaniu zawodu diagnosty laboratoryjnego, „Journal of Laboratory Diagnostics” 2012, nr 1.

Dyk D., Badanie fizykalne $w$ pielęgniarstwie, Warszawa 2013.

Fiutak A., Klasyfikacja błędów medycznych, „Medycyna Rodzinna” 2010, nr 2.

Fiutak A., Prawo medyczne $w$ orzecznictwie z komentarzem, Warszawa 2012.

Górski A., Leksykon prawa medycznego. 100 podstawowych pojęć, Warszawa 2012.

Kale E., Syed H.R., Language barriers and the use of interpreters in the public health services. A questionnaire-based survey, "Patient Educ Couns" 2010, nr 81. 
Karkowska D., Ustawa o prawach pacjenta i Rzeczniku Praw Pacjenta. Komentarz, Warszawa 2012.

Kędziora R., Odpowiedzialność karna lekarza w związku z wykonywaniem czynności medycznych, Warszawa 2009.

Lis W., Bezpieczeństwo zdrowotne pacjentów w świetle obowiąujacych przepisów, w: Prawna ochrona zdrowia pacjentów, red. J. Pacian, Warszawa 2017.

Nesterowicz M., Prawo medyczne, Toruń 2013.

Nesterowicz M., Prawo medyczne. Komentarze i glosy do orzeczeń sądowych, Warszawa 2014.

Patryn R., Określenie zasady postępowania lekarza z należytą starannościa z płaszczyzny orzecznictwa sądowego, „Prawo i Medycyna” 2017, nr 2.

Sadowska M., Błąd medyczny $w$ świetle innowacji technologicznych na rynku usług zdrowotnych, w: Prawo a technologie medyczne, red. Sadowska M., Kukuryk K., Lublin 2017.

Sieńko A., Błędy medyczne - odpowiedzialność lekarza i placówki medycznej. Jak unikać kosztownych pułapek, Warszawa 2015.

Witkowski J., Błąd lekarski: ryzyko popetnienia a kwestia obiektywizmu $w$ orzekaniu, „Prawo i Medycyna” 2009, http://www.prawoimedycyna. $\mathrm{pl} /$ index.php?str=artykul\&id=163\&PHPSESSID=28110c71 704ca4550a (dostęp: 7.02 .2017 r.).

Wnukiewicz-Kozłowska A., Pułapki codziennej praktyki lekarskiej - Błędy diagnostyczne i terapeutyczne a odpowiedzialność lekarza, „Medium Gazeta Dolnośląskiej Izby Lekarskiej” 2015, nr 4.

Zajdel J., Moc prawna standardów medycznych i wytycznych praktyki klinicznej, http://pra- wo.mp.pl/publikacje/prawomedyczne/52342, moc-prawna-standardow-medycznych-i-wytycznych- praktyki-klinicznej (dostęp: 23.03.2017 r.).

Zielińska E., Ustawa o zawodach lekarza i lekarza dentysty. Komentarz, Warszawa 2008.

Zieliński P., Kilka słów o pojęciu oraz rodzajach błędu medycznego, „Medyczna Wokanda" 2016, nr 8. 